Bebina Milovanović Arheološki institut Beograd bebina27@yahoo.com

UDK 904:726.825.042"652"(497.11)

Izvorni naučni članak

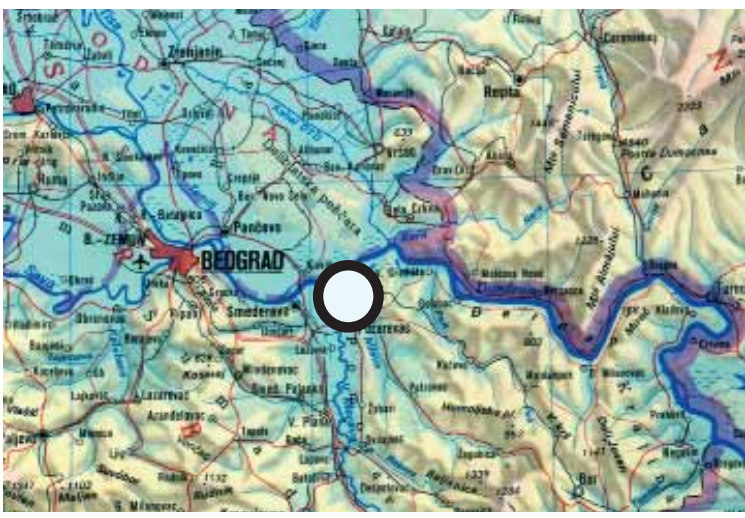

Viminacium, Stari Kostolac, Srbija

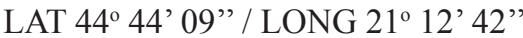

\title{
SIMBOLIKA PRIKAZANIH ŽIVOTINJA NA NADGROBNIM STELAMA IZ VIMINACIJUMA
}

\begin{abstract}
APSTRAKT
Na nadgrobnim stelama iz Viminacijuma životinje su čest dekorativni motiv u akroterijama, frizovima, a nešto ređe u nišama i zabatima spomenika. Pored dekorativne uloge, često u njima možemo prepoznati određena simbolička značenja kojima su isticana religijska shvatanja vezana za pojedina eshatološka učenja. Životinje su pojedinačno prikazivane, u paru ili u nizu što je zavisilo od položaja na spomeniku ili od šablona koji se mogao uklopiti samo u određene arhitektonske delove stele. Pored domaćih majstora koji su radili u lokalnoj kamenorezačkoj radionici od domaćeg peščara i krečnjaka, moramo računati $i$ na strane klesare koji su finalizovali poluobrađene mermerne blokove importovane iz Grčke i Male Azije.
\end{abstract}

KLJUČNE REČI: STELE, SPOMENIK, VIMINACIJUM, SIMBOLIKA, ŽIVOTINJE

\section{UVOD}

$\mathrm{Na}$ nadgrobnim stelama iz Viminacijuma se mogu izdvojiti motivi različitog simboličkog značenja ili su to samo dekorativni elementi koji su vremenom izgubili simbolički značaj. Nadgrobne stele arhitektonskog tipa nose bogatu reljefnu dekoraciju prikazanu u zabatu, frizu, niši, međupolju ili soklu. To su najčešće vegetabilni motivi, geometrijski i astralni, ili nešto složenije kompozicije sa prikazima mitoloških scena, fantastičnih i morskih bića u kombinaciji sa zoomorfnim predstavama. Često nam kombinacije različitih predstava govore o zanimanju pokojnika, njegovoj religijoznoj pripadnosti ili su to samo ustaljeni šabloni iz klesarskih radionica koje su putem slučajnog odabira naručivali dedikatori. U ovom radu su predstavljeni zoomorfni motivi koji najčešće krase frizove stela, uglove zabata (akroterije), a nešto ređe sam zabat, nišu ili sokl spomenika. Tematika rada se isključivo odnosi na simboliku životinja koje su prikazane na stelama, dok su ostali dekorativni elementi kao i sam natpis u ovom slučaju zanemareni. ${ }^{1}$ Obrađeno je devet različitih životinja koje se ponavljaju na nadgrobnim stelama u zabatu, akroterijama, frizu ili soklu. Navedene životinje su prisutne na

1 Nadgrobne stele sa Viminacijuma je publikovala M. Mirković, Inscriptions de la Mesie Superieure, Vol. II, Viminacium et Margum, Beograd, 1986. 
dvadeset jednom spomeniku. Za razliku od stela koje su u celosti očuvane, prisutni su i fragmenti spomenika kod kojih su očuvani samo delovi spomenika sa određenim prikazima životinja. Radom su obuhvaćeni i spomenici koji su nekada bili celi, ali su vremenom oštećeni ili su izgubljeni, ali su nam poznati iz ranijih opisa.

\section{I - LAVOVI}

Lavovi na stelama iz Viminacijuma prisutni su kao završeci spomenika koji su posebno klinovima pričvršćivani (slika broj 1,2,3) ili su u samom zabatu kao sastavni deo spomenika (slika broj 5). Jedino je na steli (slika broj 4) lav prikazan u sceni lova, odnosno u trenutku kada napada jelena.

Lav kao simbol Sunca, vlasti i moći još je u Mesopotamiji imao profilaktičko svojstvo na ulazu u palatu, hram ili grobnicu. Egipćani su lavove prikazivali u paru, okrenute leđima, dok su im glave bile okrenute prema istoku, odnosno zapadu. U tim slučajevima simbolizovali su sunčevu putanju. ${ }^{2}$ Sipmbolišući Sunce i sunčevu energiju lav se tretira kao vatreni princip. Takvo tumačenje je poteklo sa Istoka gde se verovalo da se iznad nebeskog svoda nalazi velika voda, a iznad nje vatreni pojas, odnosno vatrena reka u kojoj su se palile zvezde. Identično eshatološko učenje su prihvatili Grci i Rimljani koji su očišćenje duše posle smrti vršili posredstvom vatre, da bi hrišćani lava takođe preuzeli kao simbola nebeske vatre koju su svi preminuli morali preći radi očišćenja. ${ }^{3} U$ grčkoj umetnosti lavovi su tretirani i kao simboli vrline i čuvali su grobove onih koji su herojski poginuli. U Mitraizmu je lav takođe smatran vatrenim simbolom. Na mitraističkim ikonama lav je obično prikazan u nizu - Okean - Petrogen - lav, što je simbolizovalo Mitrino rođenje okruženo vodom i vatrom. ${ }^{4}$ Preko Mitraizma koji je u doba cara Vespazijana zahvatio Rim, a širili su ga najpre trgovci i legionari sa Istoka, lav u rimskoj umetnosti dobija sve zastupljenije mesto, da bi car Komod postao jedan od posvećenih mista, dok su Dioklecijan, Galerije i Licinije obnovili Mitrino svetilište. ${ }^{5}$

2 Chevalier, Gheerbrant, 1987, 345.

3 Vasić, 317.

4 Zotović, 1994, 123-130.

5 Zotović, 1973, 106.

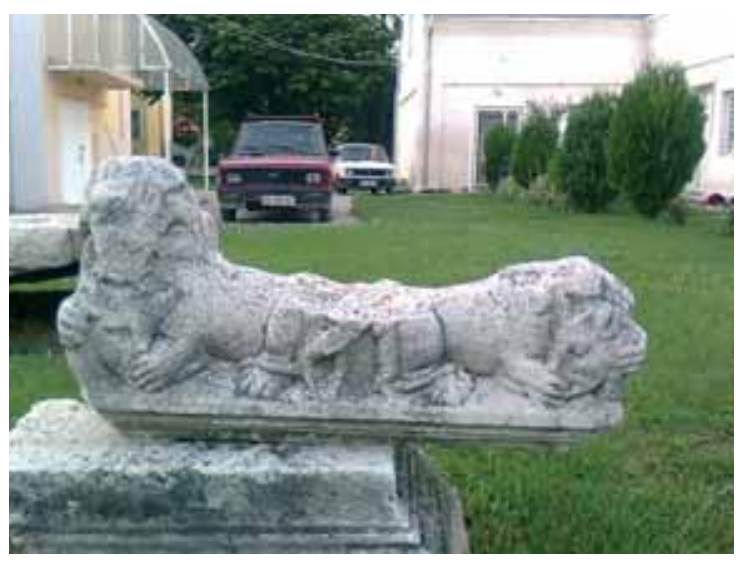

Slika 1. Lav (fotografija B. Milovanović)

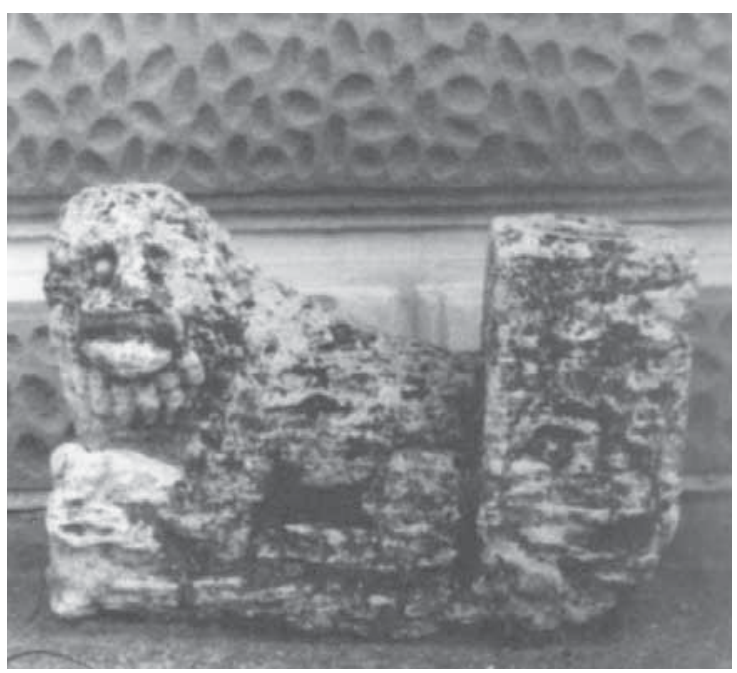

Slika 2. Lav (Zotović, 2003, 94).

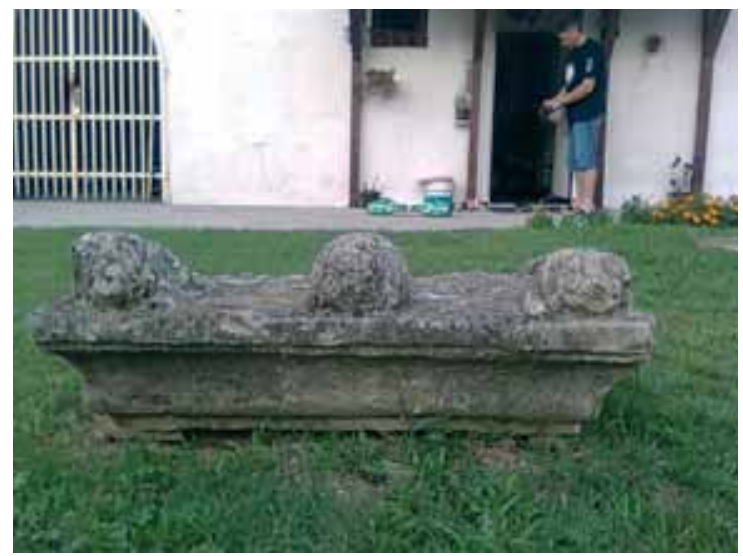

Slika 3. Lavovi (fotografija B. Milovanović) 


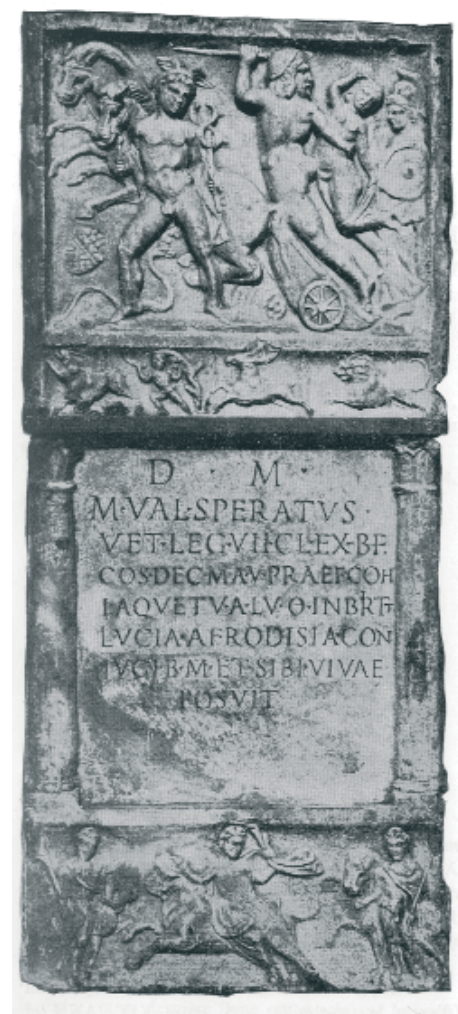

Slika 4. Stela (Mirković 1986, 130)

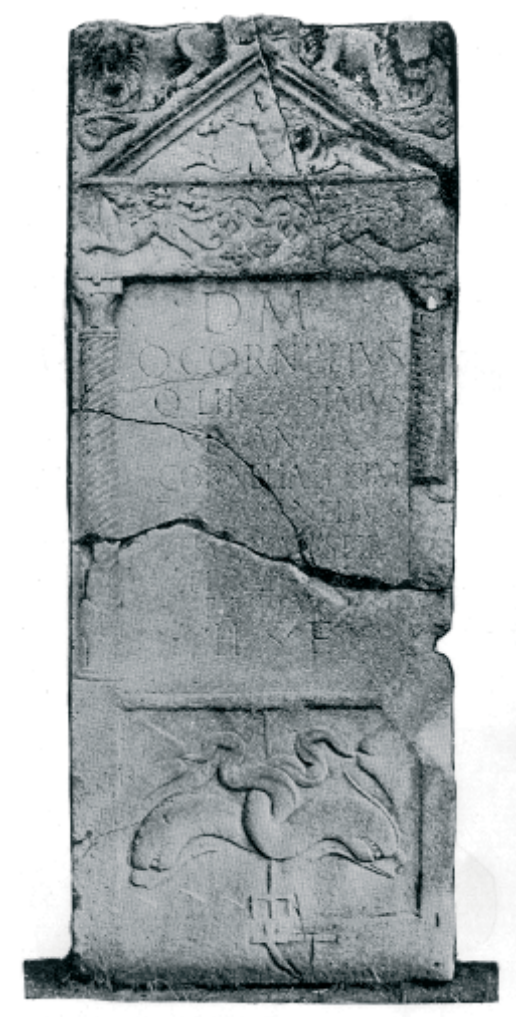

Slika 5. Stela (Mirković 1986, 167)
Lavove na stelama iz Viminacijuma možemo podeliti u dve grupe:

1 - lav u sceni lova (slika broj 4)

2 - lavovi u funkciji akroterija kao sastavni deo stele u uglovima zabata (slika broj 5) ili kao odvojeni arhitektonski elementi na samostalnim kamenim bazama između kojih su različite predstave: glava Atisa ili Dadofor ? (slika broj 1), glava Meduze (slika broj 2) i kugla (slika broj 3).

Lav prikazan u sceni lova obično napada bika, divljeg vepra ili jelena kao što je slučaj na steli iz Viminacijuma (slika broj 4). Navedeni motiv vodi poreklo sa Orijenta, a u doba Rimljana je često prisutan na spomenicima Dakije, Mediterana, Bliskog istoka, Grčke i samog Rima. Poznat je primer scene love sa spomenika iz Skelana. Simbolički posmatrano motiv proždiranja jedne žiotinje od strane druge, predstavlja smenu dana i noći; leta i zime; umiranja i vaskrsenja. ${ }^{6}$

Lavovi u funkciji akroterija su najpre posvedočeni na spomenicima u dolini Pada u severnoj Italiji, odakle prelaze na istočnu obalu Jadrana (lokaliteti: Ljubuško, Bratunac i Boros), centralnu Dalmaciju (Podrinje i Polimlje), Panoniju (Sirmijum), Gornju Meziju i Dakiju. ${ }^{7}$ Hronološki pripadaju periodu od I veka da bi vrhunac dostigli tokom druge polovine II veka, a prisutni su do sredine III veka.

Lavovi na posebnim kamenim postoljima su najpre izazivali sumnju kod naučnika jer su nalaženi nezavisno, odnosno odvojeno od stela. Međutim, vremenom se pokazalo da su uglavnom bili sastavni deo nadgrobnih spomenika na kojima su gvozdenim klinovima pričvršćivani. ${ }^{8}$ Lavovi na stelama iz Viminavijuma su heraldički postavljeni u ležećem položaju sa glavama an face i sa plenom u prednjim šapama. Taj plen je najčešće ovnujska glava (slike broj 1,5 , možda i slika broj 2). Isti motiv je poznat na spomenicima rajnskih provincija, zatim u Noriku, Panoniji, Dalmaciji i Gornjoj Meziji, dok ga u Donjoj Meziji i Makedoniji nema. Po Šoberu lavovi sa ovnujskim glavama pripadaju Kibelinom kultu, jer su lavovi vukli njena kola, a ovnovi su njene žrtvene životinje. ${ }^{9}$ Kibelin je kult poštovan u Rimu od sredine II veka. Osim ovnova u kandža-

6 Vasić, 136.

7 Vasić, 123-130.

8 Zotović, 2003, 87-96.

9 V. Kondić, 1965, 195-197. 
ma, lavovi su međusobno razdvojeni pojedinim prikazima u sredini. Tako se glava Atisa povezuje sa Kibelinim kultom. Analogni primeri su poznati iz Sirmijuma, Taurunuma i Basijana. ${ }^{10} \mathrm{Na}$ spomeniku (sl br. 1) je između lavova stojeća figura od koje je sačuvan donji deo nogu i verovatno deo baklje. Prikaz se tumači kao Dadofor ili Atis sa prebačenom levom nogom preko desne i sa spuštenom bakljom. Navedenu kompoziciju bi smo mogli vezati za Mitrin kult u kome su Dadofori kao bakljonoše bili posmatrači tauroktonije. ${ }^{11} \mathrm{U}$ ovom slučaju Dadofor se poistovećuje sa Genijem smrti jer drži spuštenu baklju. Ukoliko je u pitanju Atis, onda bi navedena kompozicija pripadala Kibelinom kultu. Interesatno je napomenuti da na glavi levog lava stele iz Viminacijuma (slika broj 1) je manje kružno udubljenje koje ukazuje na neki dodatak iznad glave. Slična udubljenja su konstatovana na temenom delu glava lavova iz Olbije. Ove otvore možemo povezati sa lavovima na medaljonu iz Donjeg Podunavlja na čijim su glavama pinije. Možda pinije možemo očekivati i u ovom slučaju. Iz Viminacijuma su poznate samostalne skulpturalne predstave lavova od kojih jedan na mestu repa ima piniju. Ove skulpture lavova se uglavnom ne tretiraju kao sastavni delovi stela, jer se po veličini razlikuju od prethodnih, ali su verovatno vezani za sakralnu arhitekturu (grobnice, hramovi). ${ }^{12}$ Iza lava (slika broj 2) na kubastom stubu je glava Meduze punih obraza i krupnih očiju. Njen zastrašujući lik je imao apotropejsku ulogu, dakle ona štiti grob i plaši zlonamernike. Slične kompozicije su poznate sa sfingom koja ima ulogu funerarne maske i datuju se u III vek. ${ }^{13} \mathrm{Na}$ oštećenom primerku (slika broj 3) se između lavova nalazi verovatno kugla ili postament pinije. Lavovi koji su sačuvani samo u donjem delu su u ležećem položaju, ali su okrenuti napred. Ukoliko predmet u sredini tretiramo kao kuglu, onda bi ona simbolizovala univerzum. Orfičari su verovali u dve koncentrične kugle koje su simbolizovale ovozemaljski i onozemaljski svet, a smrću se postizao prelazak iz jedne u drugu kuglu. ${ }^{14}$ Ukoliko je reč o postolju za piniju, takvi slučajevi su poznati iz Dakije (Apulum) datovani

10 Dautova-Ruševljan, 1983, 41.

11 Zotović, 1973, 88.

12 Zotović, 2003, 87, 89, sl. 2, kat. br. 3.

13 Zotović, 2003, 90, sl. 3, kat. br. 5

14 Chevalier, Gheerbrant, 1987, 329. u II vek. Idealna rekonstrukcija kompozicije lavova sa izdvojenim pinijama je poznata na nadgrobnom spomeniku iz Vetela. ${ }^{15}$

Navedeni primerci sa lavovima uvek su praćeni nekim dodatnim elementima koji jasno svedoče o religijskom sinkretizmu koji je vladao u Rimskom carstvu krajem II i u III veku. Mešanje kultova se najbolje vidi u prikazu Dadofora koji je preuzet iz Mitrinog kulta, a u Rimu je izjednačen sa Genijem ili pak sa Atisom.

Navedeni spomenici iz Viminacijuma hronološki pripadaju periodu od druge polovine II veka do kraja III veka, odnosno periodu religijskog sinkretizma Rimskog carstva. Viminacijum je $u$ to vreme bio pogodan za razvoj i širenje različitih religijskih i kulturnih elemenata koji su se putem vojske i civilnih doseljenika infiltrirali i ostali zabeleženi u sakralnoj umetnosti.

\section{II - PANTERI}

U frizu stele iz Viminacijuma (slika broj 5) panteri flankiraju krater iz koga izlazi vinova loza. Heraldički su prikazani, odnosno okrenuti su leđima jedan od drugog. Ove životinje se mogu tretirati kao Dionisovi čuvari vinove loze i vina. Imaju identičnu simboliku kao i lavovi koji su češće prikazivani pored kratera iz koga izlazi vinova loza, a takvi primerci su poznati iz Italije (Akvileja), Dalmacije (Solin, Zadar, Vitin, Bratunac) ${ }^{16}$ i Gornje Mezije (područje Kosmaja). Profilaktička uloga lavova i pantera je u ovom slučaju iskorišćena u Dionisovom kultu, a sama ideja je potekla sa Istoka odakle je prihvaćena najpre kod Grka, a zatim Rimljana. Preko rajnske oblasti, Norika, Dalmacije i Panonije stiže u Gornju Meziju gde dominira tokom druge polovine II do početka III veka. ${ }^{17}$

\section{III - DELFIN}

Na stelama Viminacijuma delfini su prikazani u spoljnim trouglovima zabata, odnosno u akroterijama (slike broj 6, 7, 8, 9, 10, 11). U soklu stele (slika broj 5) se nalaze dva delfina ukrštenih repova sa trozupcem koji u ustima drže morsko

15 Zotović, 2003, 89, prilog 1.

16 Vasić, 319.

17 Dautova-Ruševljan,1983, 77-78. 


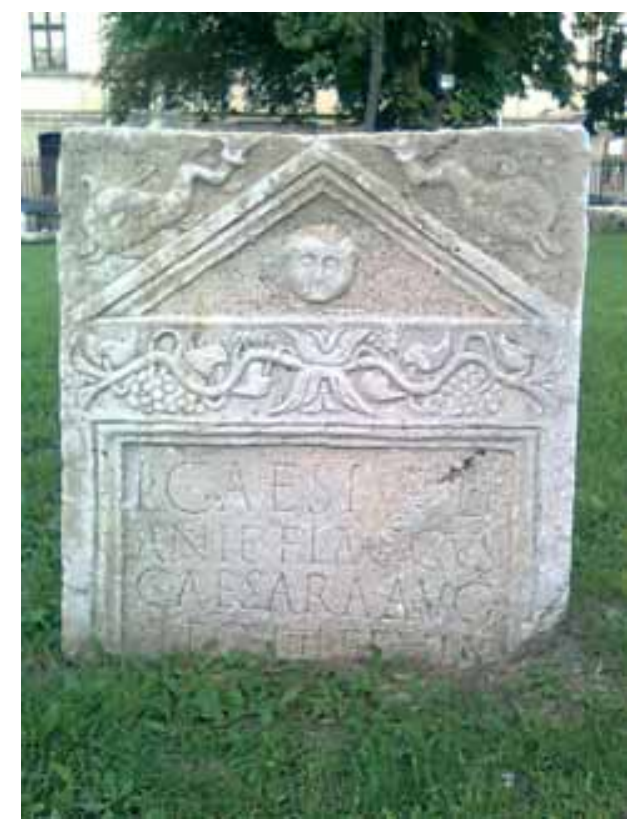

Slika 6. Stela (foto B. Milovanović)

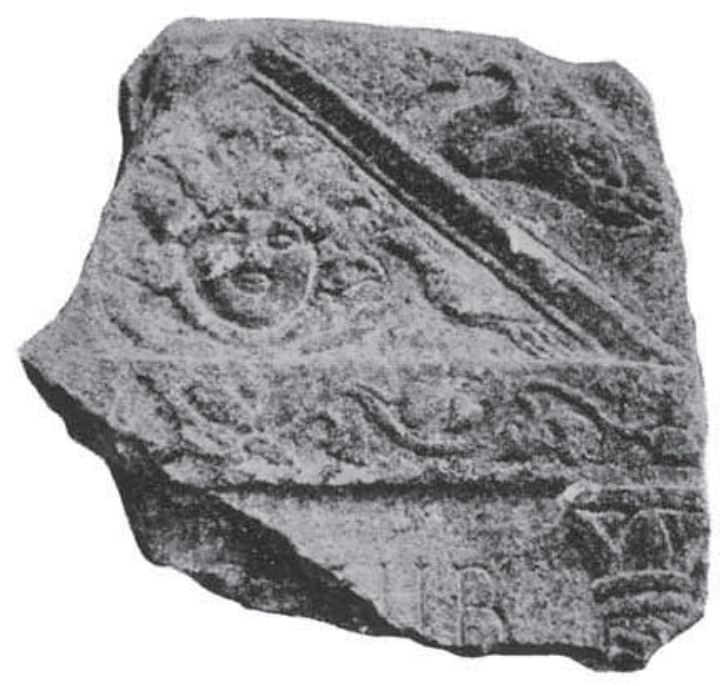

Slika 7. Stela (Mirković 1986, 172)

čudovište. Simbolika delfina se vezuje za vodu kao njihovo prirodno boravište. Mnoga božanstva su iz grčke mitologije preuzimala oblik delfina kako bi došla do određenog cilja. Tako se Apolon pretvara u delfina da bi došao do Krisa, pristaništa na Delfima. Na Apolonovom tronošcu je bio prikazan delfin, kao simbol proricanja, mudrosti i opreznosti. ${ }^{18}$ Delfin je povezan sa Posejdonom uz čiju je pomoć zadobio ljubav Amfitrite. ${ }^{19}$ Stoga je

18 Chevalier, Gheerbrant, 1987, 132-133.

19 Srejović, Cermanović, 1992, 356.

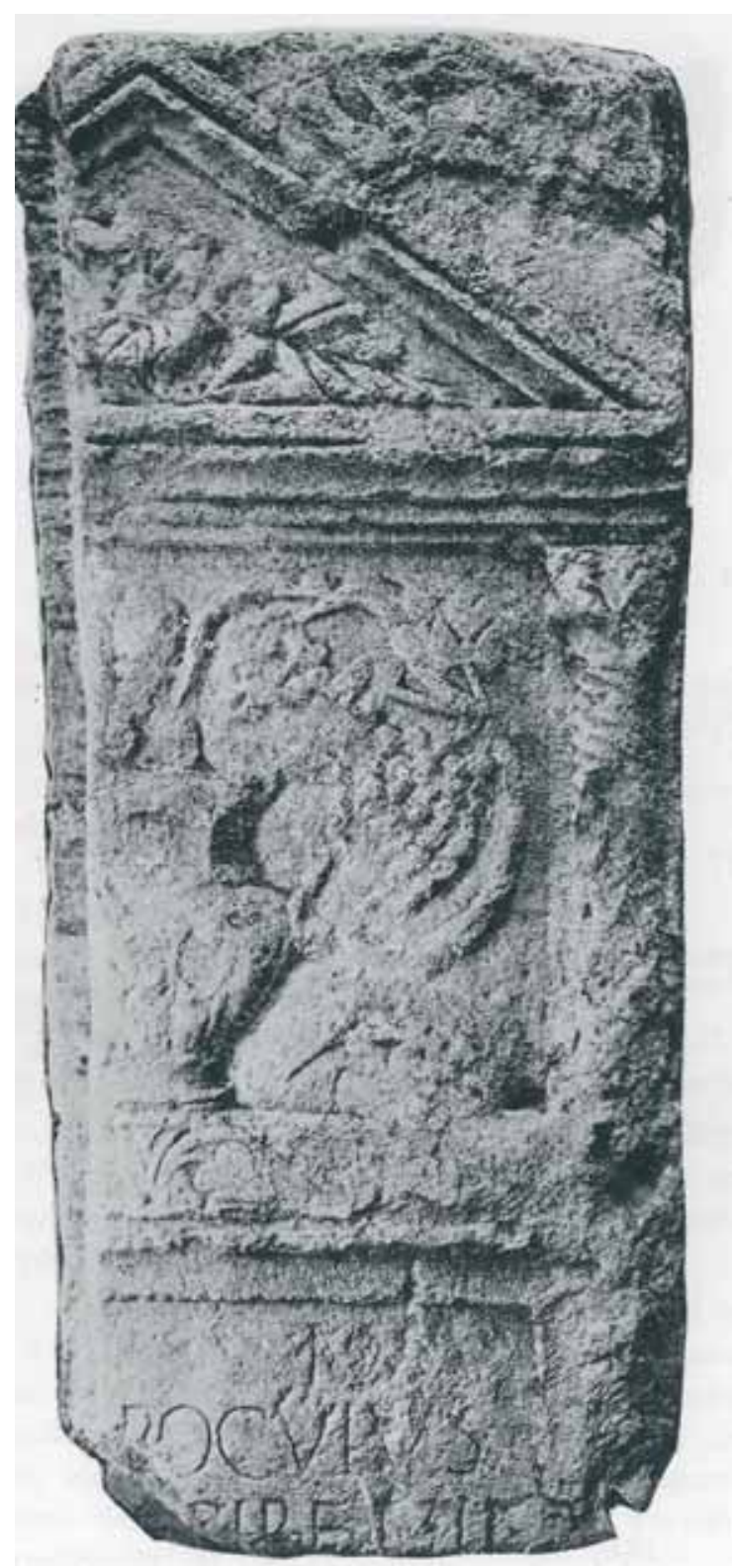

Slika 8. Stela (Mirković 1986, 166)

delfin jedan od Posejdonovih atributa zajedno sa trozupcem i konjem. Dionis je gusare koji su ga napali pretvorio u delfine. A inače su delfini poznati kao spasioci davljenika. Delfin kao simbol Okeana vezuje se i za duše umrlih koje putuju do Ostrva Blaženih, tako da postaje psihopomp koji prevozi duše umrlih do njihovog odredišta. ${ }^{20}$ C̆esto je u Grčkoj umetnosti prikazan čovek koji jaše delfina, ovim je simbolično prikazana njegova funkcija psihopompa. Stela sa Meduzom u zabatu

20 Vasić, 310. 
i delfinima u akroterijama (slika broj 7) opravdava ulogu delfina kao psihopompa koji prenosi duše umrlih do Meseca koga simboliše Meduza. Analogni primerci su poznati iz Panonije datovani u drugu polovinu I i u II veku. Delfini sa rozetom u zabatu (slike broj 8,10 i 11) koja simbolizuje Sunce, česti su u Italiji, Dalmaciji i Dakiji od I do III veka. ${ }^{21}$

Delfin kao simbol Posejdona je često prisutan na spomenicima Italije. Na frizu Agripinih termi iz Hadrijanovog doba, delfini su prikazani sa glavama dole, a između njih trozubac i školjka. Na ravenskim stelama često srećemo identičan prikaz delfina sa trozupcem ili školjkom, gotovo identičan sa stelom iz Viminacijuma (slika broj 5). U Dalmaciji je motiv delfina omiljen na spomenicima iz Duvanjskog, Livanjskog i Glamočkog polja. ${ }^{22}$ Inače je ovo tipičan rimski motiv koji je dominirao u severnoj Italiji i zapadnim provincijama, dok ga u istočnim provincijama sporadično srećemo u Gornjoj Meziji (Viminacijum, Singidunum, Skupi, Ratiarija) i Dakiji. ${ }^{23}$

\section{IV - ORAO}

Na gornjem fragmentu stele (slika broj 12) u zabatu je prikazan orao raširenih krila s glavom ulevo sa po jednim bršljanovim listom u uglovima. Sličan je prikaz dat u zabatu stele (slika broj 13) u čijim su akroterijama vojne oznage legije VII Claudia.

Orao je nebeski, a pre svega solarni simbol. Tretira se kao kralj među pticama, kao što je lav kralj životinja na zemlji. ${ }^{24} \mathrm{U}$ Grčkoj mitologiji on je Zevsov pratilac i izjednačava se sa munjom i gromom. Na Istoku sunčanog boga nosi orao, a kada vladar umre, metamorfozom postaje bog Sunca i u toj apoteozi orao ga odnosi na nebo. ${ }^{25}$ Navedeni ikonografski prikaz apoteoze su sa Istoka preuzeli Rimljani.

Orao sa zabata stele (slika broj 12) može se posmatrati kao psihopomp ili kao samo Sunce na kome počivaju duše umrlih.

U zabatu stele (slika broj 13) orao je po-

21 Dautova-Ruševljan, 1983, 48.

22 Zotović, 1995, 54.

23 Kondić, 1965, 187.

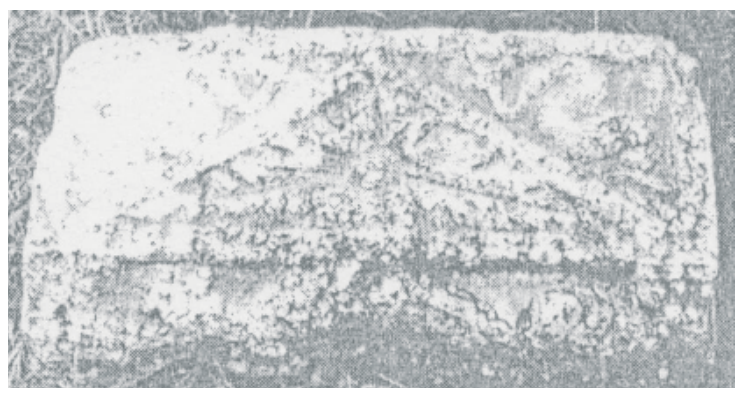

Slika 9. Stela (fotografija B. Milovanović)

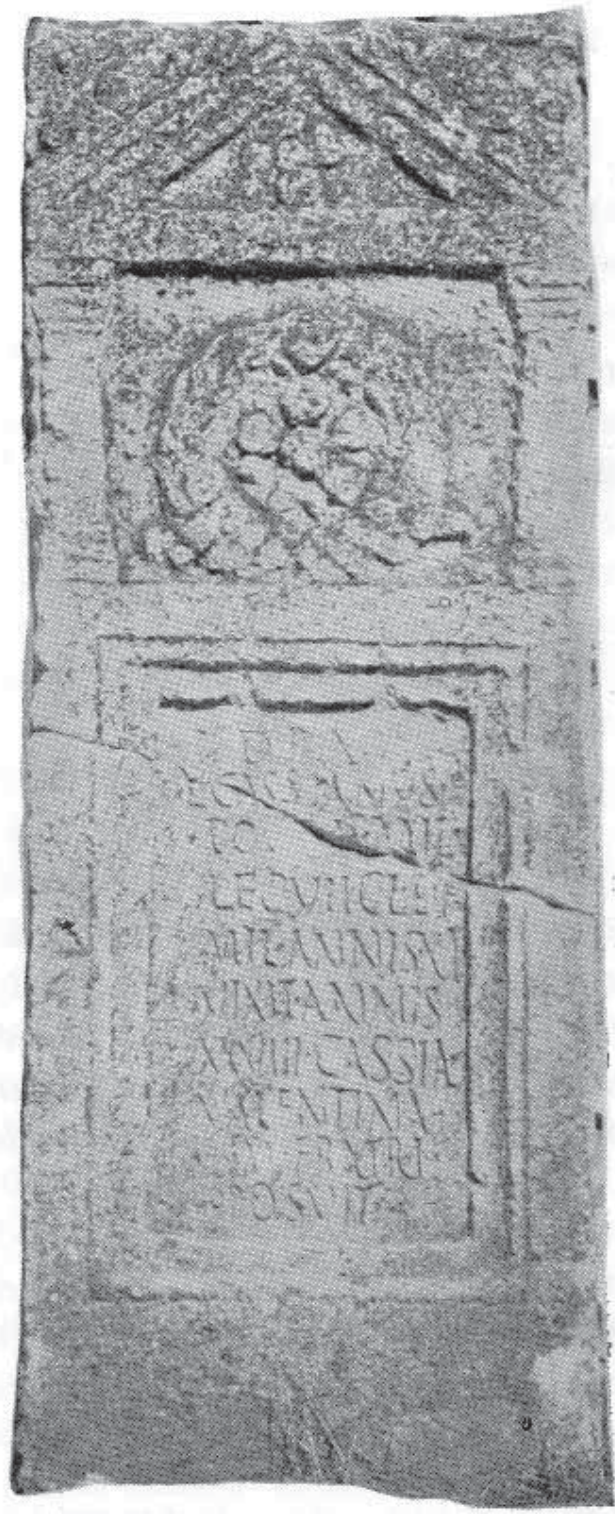

Slika 10. Stela (Mirković 1986, 141)

24 Chevalier, Gheerbrant, 1987, 459.

25 Zotović, 1995, 58. 


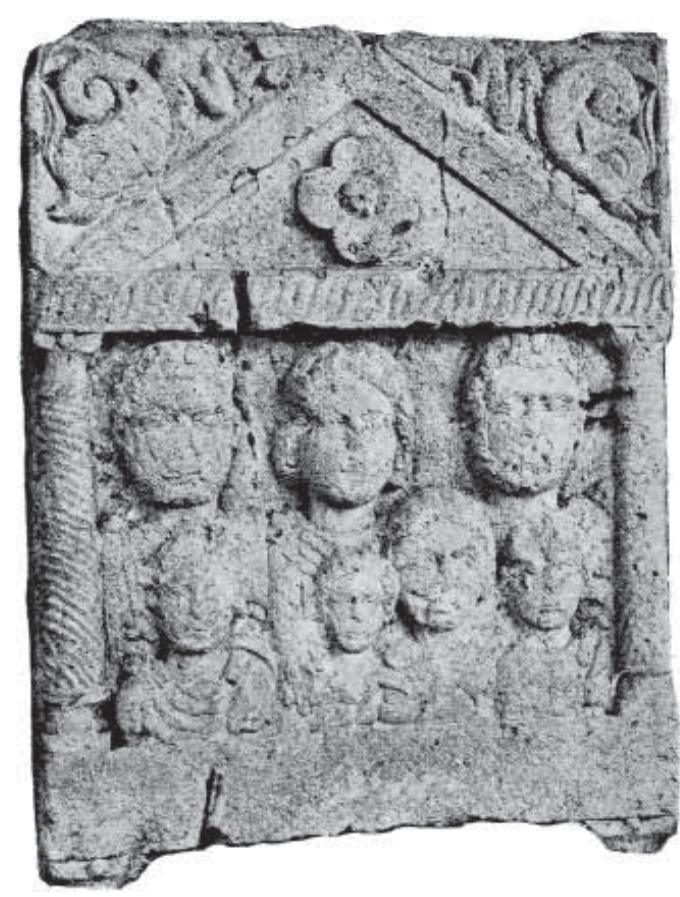

Slika 11. Stela (Mirković 1986, 170)
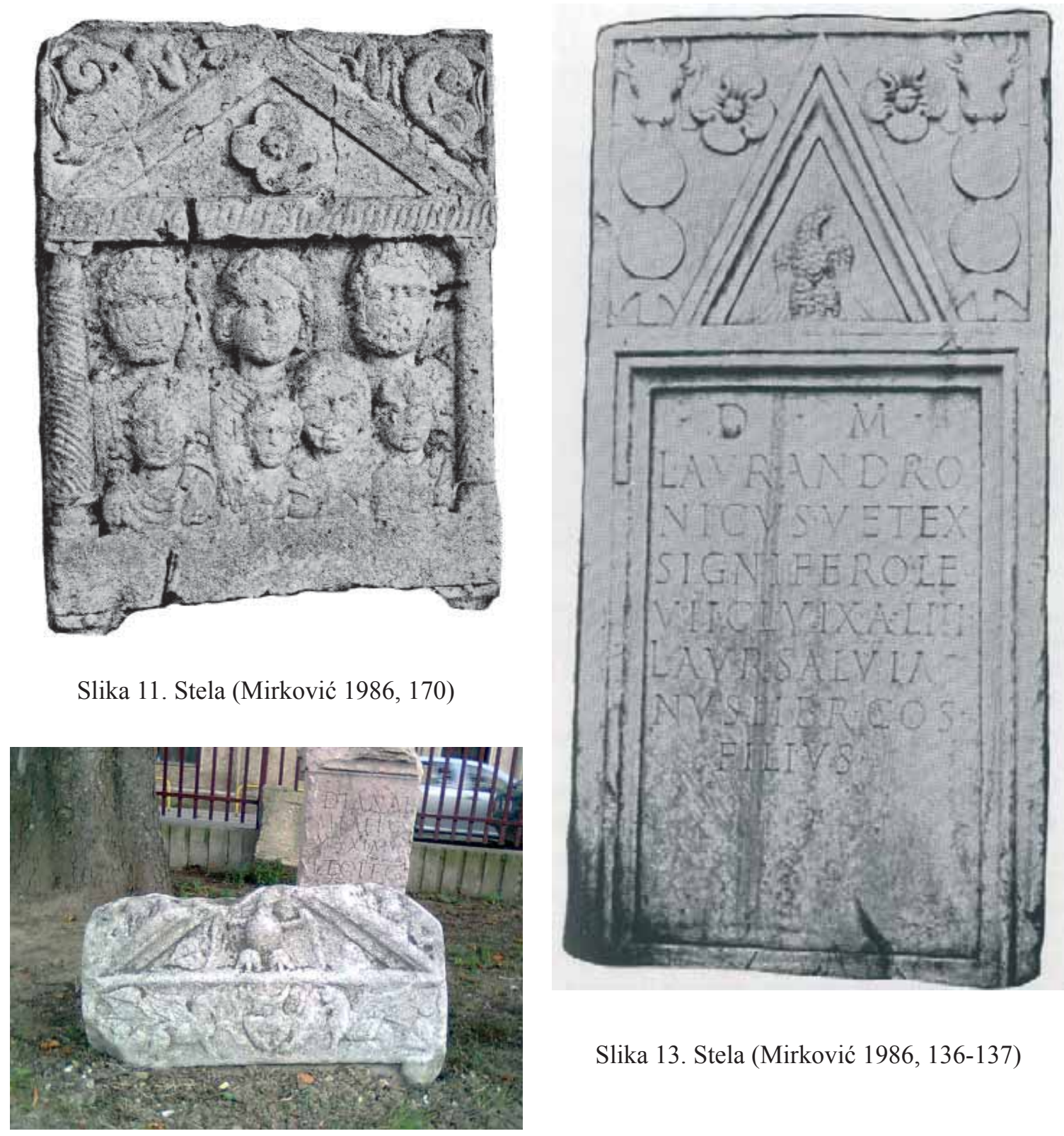

Slika 13. Stela (Mirković 1986, 136-137)

Slika 12. Stela (foto B. Milovanović)

luraširenih krila sa glavom ulevo, dok su u akroterijama vojne oznake (signa) legije VII Claudia sa glavom bika. Spomenik pripada veteranu legije VII Claudia bivšem signiferu iste legije, odnosno zastavniku. ${ }^{26}$ Sasvim je jasno što su oznake legije prikazane na spomeniku jednog signifera, dok je orao bio obavezna oznaka svake carske legije. Spomenik se na osnovu formule $D$ (is) M(anibus) najranije može datovati u II-III vek kada se navedena skraćenica koristi na gornjomezijskim spomenicima.

26 Mirković, 1986, 136-137, No 121. tu su poznati iz Singidunuma i Guberevca ${ }^{27}$ međutim, zastupljeniji su u zapadnim provincijama Carstva (Norik, Panonija i Dalmacija), a često je uz orla prikazana još neka ptica, kao što je slučaj na steli iz Basiana ili kao zmija na spomeniku iz Murse. ${ }^{28}$ Stele s motivom orla iz zapadnih provincija su datovane u I - II vek, dok iz Gornje Mezije u drugu polovinu II i početak III veka.

\footnotetext{
Kondić, 1965, 194-195.

28 Dautova-Ruševljan, 1983, 46.
} 


\section{V - KOMPOZICIJA „ŽIVOTINJA U TRKU“}

$\mathrm{Na}$ frizovima stela iz Viminacijuma kao čest motiv je prisutna kompozicija ,životinja u trku“. Poznati su sledeći primerci: frizovi stela (slika broj 14 - pas-medved i pas-zec; slika broj 15 - medved-konj-pas -divlji vepar; slika broj 16 pas-medved-košuta-jelen; slika broj 17- medveddivlji vepar; pas-zec i sa oštećena stela sa prikazom pas-zec-pas) ${ }^{29}$. Da bi smo objesnili navedene simboličke prikaze treba definisati simboliku svake pojedinačne životinje.

1-pas je prisutan u frizu sledećih stela (sl. br. 14, 15, 16, 17). Gototvo u svim mitologijama psu je pridavan htonski karakter, odnosno tretira se kao psihopomp. Kod Egipćana, bogovi Anubis i Tot su prikazani u vidu pasa koji uništavaju neprijatelje putem svetlosti i čuvaju vrata svetih mesta. ${ }^{30}$ Kod Grka je Kerber, čuvar Podzemlja, prikazan sa tri pseće glave. ${ }^{31}$ Pas je takođe i Hekatin pratilac koji zajedno sa demonima i utvarama juri kroz noć i zavijanjem najavljuje dolazak htonske boginje. ${ }^{32}$ Zavijanje pasa kao najava predstojeće smrti zastupljena je i danas u verovanjima mnogih naroda pa i Slovena. Hermes kao glasnik bogova iako nije htonsko božanstvo, nekada za pratioca ima psa i to u slučajevima kada ima funkciju psihopompa, odnosno vodiča duša u podzemni svet. ${ }^{33}$ Poznato je da šamani nose odeću od štavljene pseće kože što im po njihovom verovanju olakšava moć proricanja koja se pripisuje psu. ${ }^{34}$ Pas je poznat i kao Asklepijev čuvar, stoga mu se pripisuju i lekarske sposobnosti.

2 - medved je prikazan na frizu stela (slika broj 14, 15, 16 i 17). Simbolika ove životinje se vezuje za Kelte kod kojih je tretiran kao simbol ratnika i često je prikazivan naspram vepra - simbola sveštenstva. Galske narodne priče često govore o sukobu između medveda i vepra, odnosno carstva i sveštenstva. ${ }^{35} \mathrm{U}$ frizu oštećene stele (slika broj 17) upravo je prikazana scena sukoba medveda i vepra.

29 Nije priložena fotografija poslednje stele jer je spomenik oštećen.

30 Chevalier, Gheerbrant, 1987, 476.

31 Srejović, Cermanović, 1992, 200.

32 Srejović, Cermanović, 1992, 449.

33 Srejović, Cermanović, 1992, 474.

34 Chevalier, Gheerbrant, 1987, 477.

35 Chevalier, Gheerbrant, 1987, 396.

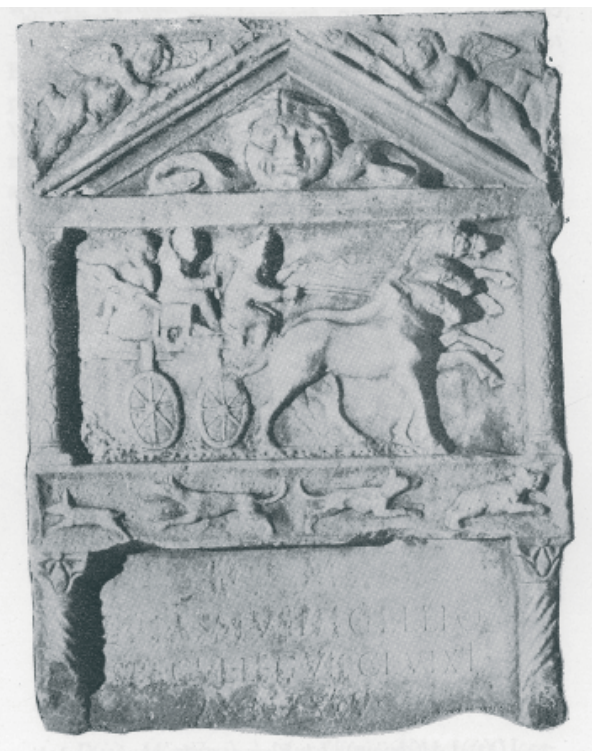

Slika 14. Stela (Mirković 1986, 128)

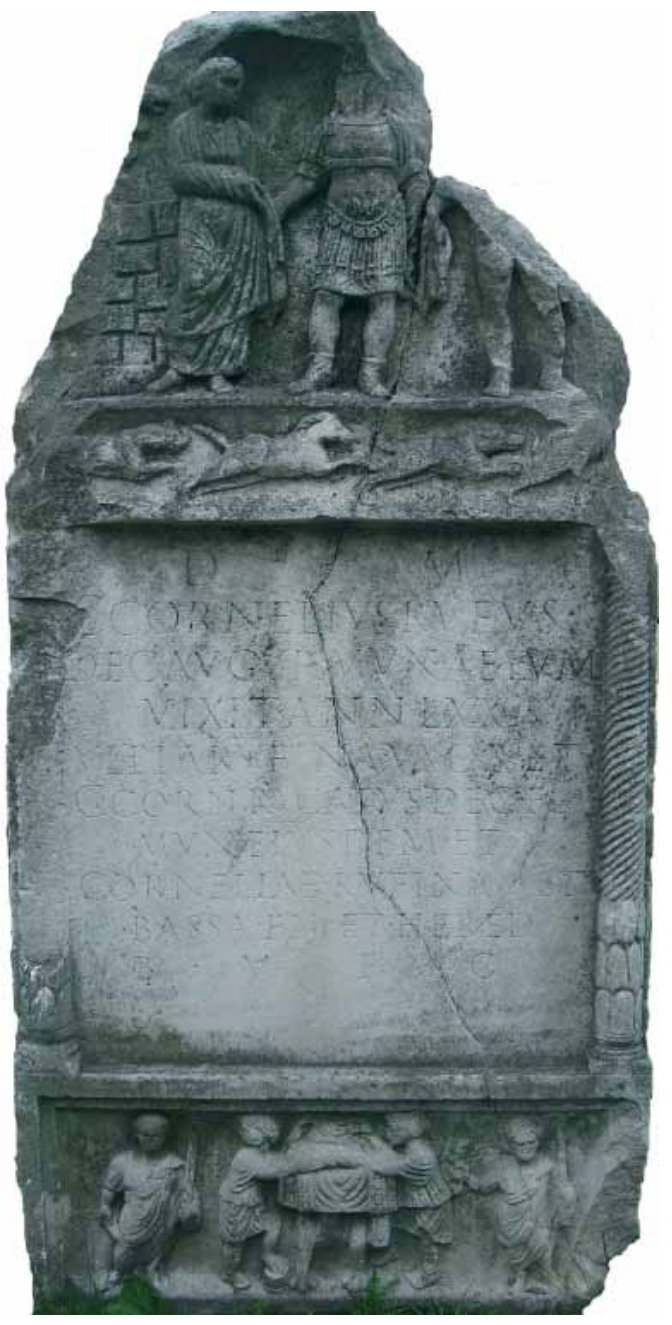

Slika 15. Stela (Mirković 1986, 110-111) 


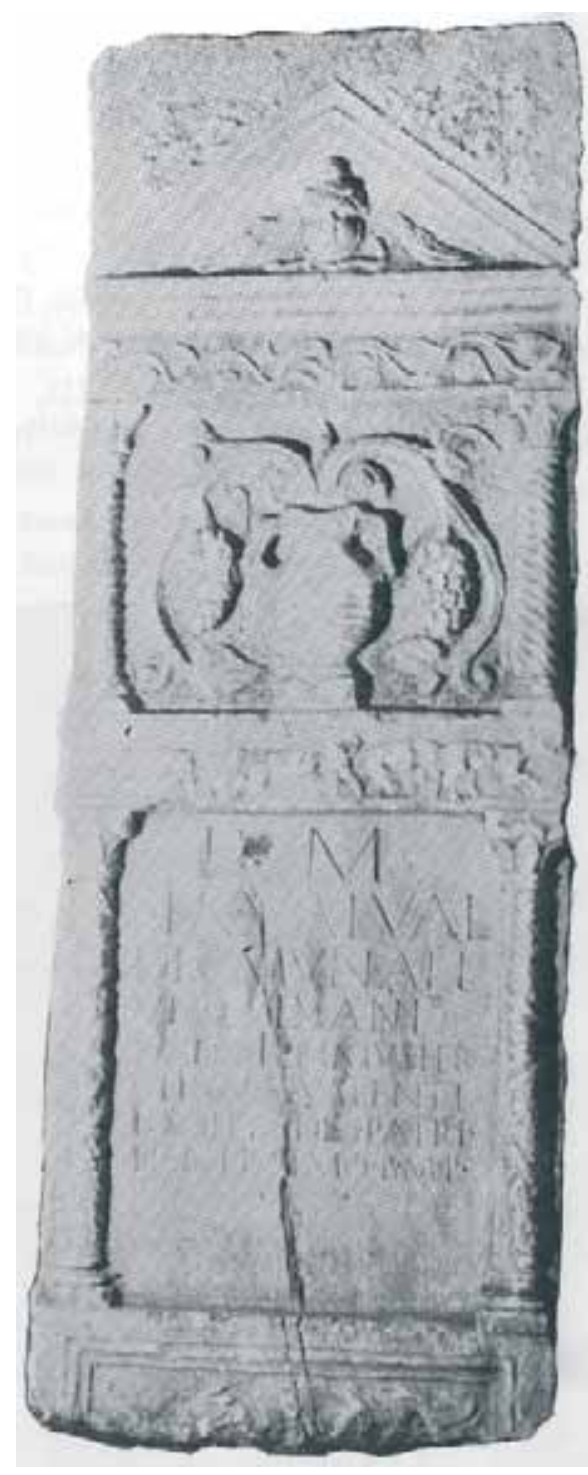

Slika 16. Stela (Mirković 1986, 113)

3 -jelen i košuta su prikazani u frizu stele (slika broj 16) i u sceni lova na steli (slika broj 4). Jelenji rogovi se često povezuju sa drvetom života i simbolizuju prirodni tok - umiranje i rađanje. U grčkoj mitologiji jelen je simbol brzine i hitrosti. Četiri košute vuku Artemidine kočije, a petu goni Herakle sve do zemlje Hiperborejaca. Ova košuta simbolizuje mudrost koju je teško stići, odnosno steći. Kod Kelta je lov na košutu tretiran kao traženje mudrosti koja se nalazi ispod drveta jabuke, odnosno stabla spoznaje. ${ }^{36}$

4 - divlji vepar je prikazan u frizu stela (slika broj 15 i 17). Kao simbol duhovne moći jav-

36 Chevalier, Gheerbrant, 1987, 226-227. lja se nasuprot medvedu koji poseduje svetovnu moć. Lov na divljeg vepra u Galiji i Grčkoj tretira se kao slika duhovnog koju progoni svetovno. ${ }^{37}$ Navedenu simboliku ilustruju mitovi o Heraklu koji lovi erimanskog vepra i o Meleagru koji uz pomoć Tezeja i Atlante lovi kalidonskog vepra. ${ }^{38}$ U navedenim mitovima vepar je simbol razvrata i brutalnosti, dok u hrišćanstvu simbolizuje demona zbog silovitosti i štete koju ostovlja za sobom.

5 - zeca u frizu stela (slika broj 14 i 17) progoni pas. Zec koji noću spava a tokom dana je budan, tretira se kao lunarna životinja, jer se može porediti sa Mesecom. Stoga je simbol neprekidnog obnavljanja života. Kod Egipćana je Oziris često predstavljan u obliku zeca, a poznato je da je to bog periodičnog obnavljanja. Kao lunarna životinja, zec simboliše i plodnost. Kako se povezuje sa razmnožavanjem bića, obiljem i bujnošću, zec se tumači kao nosilac neumerenosti, pohote i rasipnosti.

$\mathrm{Na}$ nadgrobnim spomenicima simboliše obnavljanje života, umiranje i ponovno rađanje. Danas u narodu postoji verovanje da prelazak zeca preko puta ima loš ishod za čoveka. Zec kao nagoveštač smrti postaje glasnik mrtvih. Na skulpturi iz Stojnika (Kosmaj; III vek) je prikazan Hipnos koji na grudima drži zeca što potvrđuje njegovu vezu sa svetom mrtvih. ${ }^{39}$

\section{SIMBOLIKA MOTIVA „ŽIVOTINJA U TRKU“}

U sredini friza stele (slika broj 14) dva psa prikazana su u napadu na medveda, odnosno zeca. U ovom slučaju pas je simbol smrti koja progoni životnu snagu prikazanu kroz medveda i zeca. Prizor ističe borbu između života i smrti i daje nadu u obnovu i vaskrsenje.

Prikaz medveda, konja, psa i divljeg vepra koji trče u nizu na frizu stele (slika broj 15) može se povezati sa simboličnom predstavom rađanja iz tamne prvobitne materije, možda i same materice koju simboliše medved, dok konj predstavlja čoveka u punoj snazi životne mladost i stvaralačke moći. Istovremeno konj u galopu nagoveštava brzinu mladalačkog žara koji poput konjske

37 Chevalier, Gheerbrant, 1987, 743.

38 Srejović, Cermanović, 1992, 254, 462.

39 Jacanović, 1995-1996, 11-12. 
hitrosti nestaje jer ga sustiže smrt u obliku psa. Dakle, nakon rođenja i kratkotrajnog života dolazi smrt, dok divlji vepar kao nosač duhovne snage simboliše besmrtnost i neprekidno obnavljanje. Navedene životinje nisu slučajno prikazane ovim redom, već su date s određenim ciljem. Jedno od mogućih tumačenja scene može se poistovetiti i sa godišnjim dobima: medved - zima, konj -proleće, pas - leto i vepar - jesen.

Friz stele (slika broj 16) je oštećen ali se mogu nagovestiti prikazi sledećih životinja: pas, medved, jelen i košuta. Za razliku od životinja na prethodnom frizu, ovde su životinje date u gotovo mirnom stavu. Navedene životinje lako se mogu povezati sa osnovnim životnim principima - umiranje i rađanje.

U frizu stele (slika broj 17) levo su medved i divlji vepar u direktnom sukobu svetovnog (medved) i duhovnog (vepar), dok su na desnoj strani pas koji progoni zeca, odnosno smrt koja progoni žrtvu koja poput zeca hitro beži.

Zec između dva psa na frizu oštećene stele pored toga što predstavlja klasičnu scenu iz lova, može da simbolizuje kao i u prethodnom slučaju žrtvu (zec) koju sustiže smrt (pas).

\section{ZAKLJUČAK}

Gotovo svi do sada navedeni motivi životinja na spomenicima iz Viminacijuma mogu se povezati sa simboličkim prikazima života i smrti. Često u sebi sadrže oba prirodna fenomena nastojeći da istaknu večitu borbu između ova dva principa. Rimska izreka „Mors janua vitae“, duboko je ušla u svest Rimljana koji su nastojali da prikazima pojedinih životinja naglase ovu tematiku predstavljajući je na spomenicima sepulkralnog karaktera. U svim religijama smrt izaziva strah kod čoveka, stoga se stvara vizija o drugom, večnom životu kako bi se ublažio taj strah.

$\mathrm{Na}$ osnovu materijala, reljefne obrade i dekorativnih elemenata, stele iz Viminacijuma su uglavnom delo domaćih majstora. Rađene su od krečnjaka boljeg ili lošijeg kvaliteta, peščara (slika broj 2, 3, 8-12 i 16) i mermera (slika broj 1, 4-6; 13-15 i 17). Peščar i krečnjak su domaćeg porekla, možda iz tašmajdanskih kamenoloma. Kamenolomi u blizini Viminacijuma nisu konstatovani, a najbliži bi bio tašmajdanski. Mermer

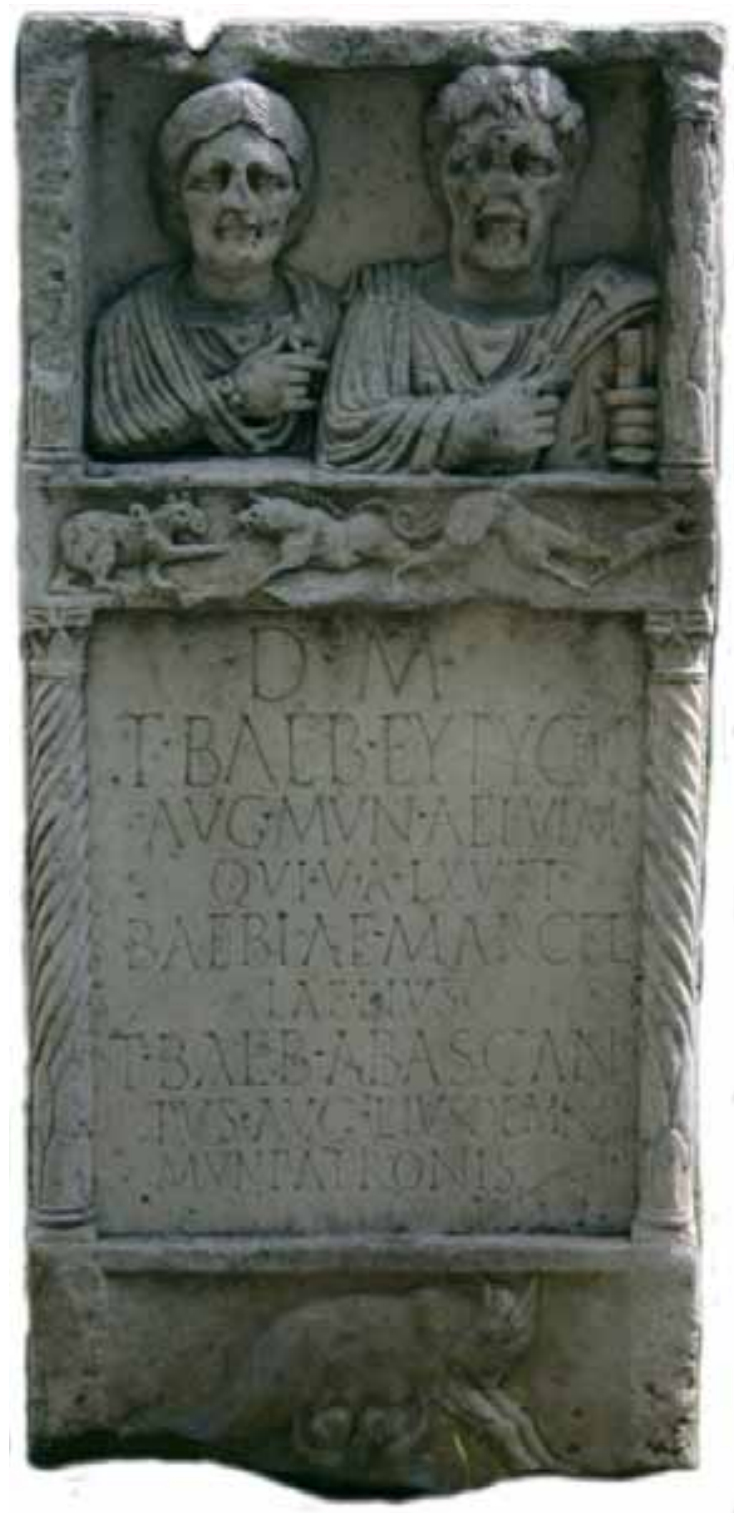

Slika 17. Stela (fotografija N. Mrđić)

je uglavnom uvožen verovatno iz Grčke i Male Azije. Kvalitetan krupnozrnasti mermer je poznat iz Prokonesa (ostrvo Marmara), a sitnozrnasti iz Pentelikonskih kamenoloma blizu Atine, Tasosa, Lezbosa i Naksosa. Spomenici od peščara i krečnjaka jednostavnije reljefne dekoracije možemo pripisati nekom lokalnom majstoru, dok su vrhunski obrađeni spomenici od mermera sa mitološkim predstavama delo verovatno majstora iz Male Azije i Grčke. Pojedini luksuzni spomenici su importovani Crnim morem do Dunava, odakle su u poluobrađenoj formi stizali u lokalnu radionicu na finalnu obradu. Iako u Viminacijumu do sada 
nije pronađena klesarska radionica, brojni nalazi nadgrobnih spomenika i sarkofaga, ukazuju na njeno postojanje. Ako bi smo je hronološki determinisali, onda bi to bio period druge polovine II i III vek, odnosno vreme najvećeg ekonomskog i političkog prosperiteta Viminacijuma.

\section{LITERATURA}

\section{Vasić, nepublikovano}

M. R. Vasić, Nadgrobni spomenici (stele $i$ cipusi) u rimskoj provinciji Dalmaciji od I - IV veka nove ere, (doktorat, nepublikovano), Beograd.

\section{Dautova-Ruševljan 1983}

V. Dautova-Ruševljan, Rimska kamena plastika u jugoslovenskom delu provincije Donje Panonije, Novi Sad, 1983.

\section{Zotović 1973}

Lj. Zotović, Mitraizam na tlu Jugoslavije, Beograd, 1973.

\section{Zotović 1994}

R. Zotović, Rimski kameni lavovi iz zbirke Narodnog muzeja u Užicu, Saopštenja XXVI, Užice, 1994, 123-130.

\section{Zotović 1995}

R. Zotović, Rimski nadgrobni spomenici istočnog dela provincije Dalmacije, Užice, 1995.

\section{Zotović 2003}

R. Zotović, Rimski kameni lavovi iz zbirke Narodnog muzeja u Požarevcu, Viminacium 1314, Požarevac, 2003, 87-96.

\section{Jacanović 1996}

D. Jacanović, Tragovi animalizma u dubovačko-žutobrdskoj kulturi bronzanog doba srpskog Podunavlja, Viminacium 10, Požarevac, 1995-1996, 5-18.

\section{Kondić 1965}

V. Kondić, Sepulkralni spomenici sa teritorije rimske provincije Gornje Mezije, Beograd, 1965.
Mirković 1986

M. Mirković, Inscriptions de la Mesie Superieure, Vol. II, Viminacium et Margum, Beograd, 1986.

\section{Srejović 1992}

D. Srejović, A. Cermanović, Rečnik grčke $i$ rimske mitologije, Beograd, 1992.

\section{Chevalier, Gheerbrant 1987}

J. Chevalier, A. Gheerbrant, Rječnik simbola, Zagreb, 1987.

\section{SYMBOLISM OF ANIMALS DEPICTED ON TOMBSTONES FROM VIMINACIUM}

Reliefs of animal are common decoration on tombstones from Viminacium. They are often found on acroterions, freezes and rarely in nishas and on tympanuns. Although their main role is to decorate, we can recognize many symbolic meanings that emphasized different religious views and various eschatologies. Animals were carved alone, in pairs or in lines depending on the position within the monument or following pattern possible to fit only in certain architectural elements of the stelae. It must be counted both on local stonecutters and on those who came to finalize unfinished marble blocks imported from Greece or Asia Minor.

Key words: Stelae, tombstone, Viminacium, SYMBOLISM, ANIMALS 